KS. PIOTR SZCZUR* - LUBLIN

\title{
CHRZEŚCIJANIE WOBEC BOGACTWA W NAUCZANIU KLEMENSA ALEKSANDRYJSKIEGO
}

Ewangeliczna rada, której Chrystus udzielił bogatemu młodzieńcowi pytającemu o drogę prowadzącą do osiągnięcia zbawienia, aby sprzedał wszystko, co posiada, a zgromadzony w ten sposób majątek rozdał ubogim (por. Mk 10, 21; Mt 19, 21; Łk 18, 22), jest jedną z kluczowych wypowiedzi Pisma Świętego na temat stosunku chrześcijan do dóbr materialnych ${ }^{1}$. Nie dziwi więc fakt, że zdecydowana większość myślicieli wczesnochrześcijańskich analizując tę perykopę ewangeliczną ${ }^{2}$ postulowała całkowite wyrzeczenie się dóbr materialnych. Jednak obok tych radykalnych głosów pojawiały się - choć zdecydowanie rzadziej - i inne, proponujące nieco odmienne podejście do bogactwa i wartości materialnych. Do tej grupy pisarzy kościelnych należy jeden z najwybitniejszych myślicieli przełomu II i III wieku - Tytus Flawiusz Klemens³ , zwany Kle-

* Ks. Piotr Szczur - dr hab. historii Kościołą, kierownik Katedry Kistorii Kościoła w Starożytności Chrześcijańskiej, Instytut Historii Kościoła i Patrologii, Wydział Teologii KUL.

${ }^{1}$ Problem stosunku chrześcijan do dóbr materialnych był przedmiotem wielu badań. Por. I. Giordani, Il messaggio sociale di Gesú, t. 1-4, Milano 1947; L. Orabona, Cristianesimo e proprietá. Saggio sulle fonti antiche, Roma 1964; E. Patlagean, Pauvreté économique et pauvreté sociale à Byzance 4e - $^{e}$ siècles, Paris 1977; M. Simon, Cywilizacja wczesnego chrześcijaństwa I-IV w., przekład E. Bąkowska, Warszawa 1981 (passim); T. Mauro, P. Alieto, Retto uso dele richezze nella tradizione patristica. Clemente d'Alessandria, Basilio di Cesarea, Gregorio di Nazianzo, Gregorio di Nissa, Giovanni Crisostomo, Ambrogio di Milano, Agostino d'Ippona, Cromazio d'Aquileia, Torino 1985; P. Brown, Świat późnego antyku. Od Marka Aureliusza do Mahometa, przekład polski A. Podzielna, Warszawa 1991 (passim);

${ }^{2} \mathrm{Na}$ temat różnych sposobów interpretacji tej perykopy zob. Per foramen acus. Il cristianesimo antico di fronte alla pericope evangelica del ,giovane ricco”, [Studia Patristica Mediolanensia, t. 14], Milano 1986.

${ }^{3}$ J. Pałucki (Dobre bogactwo, Lublin 1992, s. 14-15) zauważa, że „Osobowość Klemensa, a także środowisko, w którym przyszło mu pracować, stały się okazją do najłagodniejszego chyba w całej wczesnochrześcijańskiej literaturze ustosunkowania się do problemu dóbr materialnych", zaś na str. 8 wyjaśnia: „niewątpliwie Klemens daleki jest w swej koncepcji od ideałów, które póź- 
mensem z Aleksandrii ${ }^{4}$. Z tego względu niniejsze rozważania stawiają sobie za cel przedstawienie nauki na temat stosunku chrześcijan do dóbr materialnych ${ }^{5}$, zawartej w jego spuściźnie literackiej ${ }^{6}$.

Klemens Aleksandryjski, którego życie datuje się na lata $150-212^{7} / 215^{8}$, jest jednym z najwcześniejszych autorów chrześcijańskich zajmujących się kwestią bogactwa oraz stosunku chrześcijan do dóbr materialnych ${ }^{9}$. Z historycznego punktu widzenia nasz autor pozostaje postacią mało znaną, jednak pisma, które pozostawił po sobie (nie wszystkie się zachowały ${ }^{10}$ ) pozwalają bliżej poznać

niej preferował monastycyzm, tj. życie pustelnicze, surowa asceza, wyrzeczenie się wszelkich dóbr materialnych".

${ }^{4}$ Szerzej na temat Klemensa Aleksandryjskiego zob. J. Niemirska-Pliszczyńska, Wstęp, w: Klemens Aleksandryjski, Kobierce zapisków filozoficznych dotyczących prawdziwej wiedzy, z języka greckiego przełożyła, wstępem, komentarzem i indeksami opatrzyła J. Niemirska-Pliszczyńska, t. 1, Warszawa 1994, s. VII-XI; F. Drączkowski, Klemens Aleksandryjski, w: Encyklopedia katolicka, red. A. Szostek i inni, t. 9, Lublin 2002, kol. 98-102; M. Kowalewska, P. Szczur, Klemens Aleksandryjski, w: Powszechna Encyklopedia Filozofii, red. A. Maryniarczyk i inni, t. 5, Lublin 2004, s. 637-641; M. Mees, Clemente di Alessandria, w: Nuovo dizionario patristico e di antichitá cristiane, (dalej: NDPAC), red. A. Di Berardino, t. 1, Genova - Milano 2006, kol. 1066-1073.

${ }^{5}$ Temat ten w literaturze przedmiotu był już niejednokrotnie podejmowany, jednak aktualność nauki Klemensa skłania do ponownego przeanalizowania jego wypowiedzi na temat stosunku chrześcijan do dóbr materialnych. Z ważniejszych opracowań można wymienić: V. Messana, L'economia nel «Quis dives salvetur». Alcune osservazioni filologische, „Augustinianum” 17 (1977), s. 133-143; C. Nardi, Clemente d'Alessandria. Quale ricco si salva? Il cristiano e l'economia, Roma 1991; Pałucki, Dobre bogactwo; C. Nardi, Quale rico si salva? La proposta di Clemente di Alessandria, „Parola, Spirito e Vita” 31 (2000), nr 42, s. 177-190.

${ }^{6}$ Zasadniczą bazę źródłową niniejszego opracowania stanowią dzieła Klemensa Aleksandryjskiego w wydaniu krytycznym O. Stählina i L. Früchtela: Clemens Alexandrinus, Paedago-

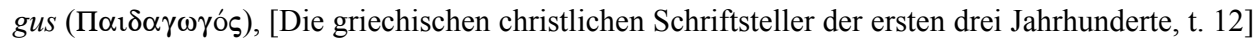

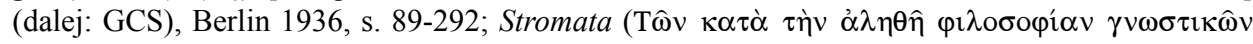

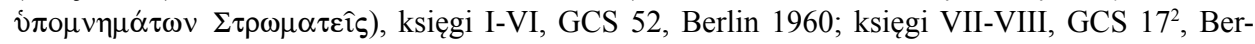

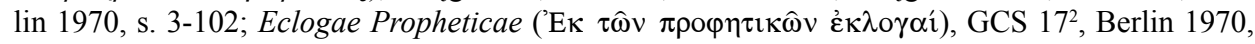

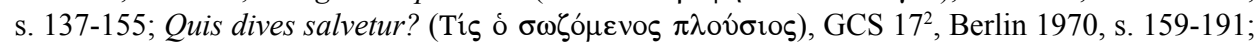

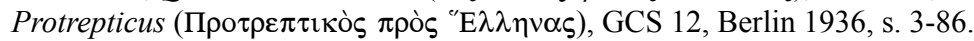

${ }^{7}$ Por. J. Wojtczak, Klemens Aleksandryjski, w: Stownik wczesnochrześcijańskiego piśmiennictwa, red. J. M. Szymusiak, M. Starowieyski, Poznań 1971, s. 249.

${ }^{8}$ Por. Mees, Clemente di Alessandria, kol. 1066; B. Altaner, A. Stuiber, Patrologia. Życie, pisma i nauka Ojców Kościoła, przekład polski P. Pachciarek, Warszawa 1990, s. 277; F. Drączkowski, Patrologia, Pelplin-Lublin 2009, s. 104-105; tenże, Klemens Aleksandryjski, kol. 98-99; Kowalewska, Klemens Aleksandryjski, s. 637.

${ }^{9}$ Podobne podejście do problemu bogactwa prezentuje autor Pasterza. Klemens Aleksandryjski znał to pismo i cenił je. Por. Clemens Alexandrinus, Stromata II 3, 5, GCS 52, s. 114; III 79, 4, GCS 52, s. 232; IV 15, 6, GCS 52, s. 255; VI 117, 3, GCS 52, s. 491; Eclogae propheticae 18, 1, GCS $17^{2}$, s. 141; Quis dives salvetur? 31, 8, GCS 172, s. 180.

${ }^{10}$ Por. Eusebius Caesariensis, Historia ecclesiastica, VI 13, 1-3, ed. G. Bardy: Eusèbe de Césarée, Histoire Ecclésiastique, [Sources chrétiennes, t. 41] (dalej: SCh), Paris 1955, s. 104-105; J. Naumowicz, Wstęp, w: Klemens Aleksandryjski, Który człowiek bogaty może być zbawiony?, Pseudo-Klemens, Zachęta do wytrwałości, [Mała Biblioteka Ojców Kościoła, t. 2] (dalej: MBOK), Kraków-Ząbki 1995, s. 9; Kowalewska, Klemens Aleksandryjski, s. 638-639. 
jego osobę i myśl ${ }^{11}$. Jego pełne imię brzmi - Tytus Flawiusz Klemens. Imię to uprawnia do postawienia tezy, że jego rodzina prawdopodobnie wywodziła się od wyzwoleńca z domu (T.) Flawiusza Klemensa, który pełnił urząd konsula w roku 95 za panowania cesarza Domicjana $(81-96)^{12}$. Jeśli powyższe przypuszczenie jest słuszne, to należy zauważyć, że rodzina Klemensa Aleksandryjskiego była, przynajmniej pośrednio, związana z rzymską klasą wyższą na przestrzeni mniej więcej trzech pokoleń. W tym miejscu warto zauważyć, że dzieje cesarstwa rzymskiego potwierdzają, iż wyzwoleńcy bogatych rodów dość często osiągali awanse społeczne i odnosili sukcesy finansowe $\mathrm{e}^{13}$. $\mathrm{Z}$ tego względu można przypuszczać, że przodkowie Klemensa osiągnęli zarówno awans społeczny, jak i sukces finansowy. Przypuszczenie to wydaje się być uprawnione, gdyż z pism Aleksandryjczyka można wywnioskować, że był on człowiekiem dość zamożnym ${ }^{14}$. Przykładowo, językiem znawcy mówi o kosztownych naczyniach wykonanych ze złota, srebra, kryształu czy alabastru, a przeznaczonych do najbardziej prozaicznych celów ${ }^{15}$. Ponadto, nie podejmując żadnej pracy zarobkowej ${ }^{16}$, mógł pozwolić sobie na podróżowanie po całym ówczesnym świecie. Nauki pobierał u kilku nauczycieli, których wspomina, aczkolwiek nie z imienia: „w Grecji był uczniem nauczyciela jońskiego, w Wielkiej Grecji (płd. Italia, Sycylia) słuchał Syryjczyka i Egipcjanina, na Wschodzie - mistrzów z Assyrii i Palestyny" ${ }^{17}$. Na ponad dwadzieścia

${ }^{11}$ Por. Naumowicz, Wstęp, s. 7.

${ }^{12}$ Szerzej na temat Flawiusza Klemensa zob. G. Bardy, 1. Clément (Titus Flavius), w: Dictionnaire d'historie et de géographie ecclésiastique, t. 12, red. A. Baudrillart, A. de Meyer, Ét. Van Cauwenbergh i inni, Paris 1953, kol. 1083; E. Peretto, Flavio Clemente, w: NDPAC II, kol. 1983.

${ }^{13}$ Por. I. A. H. Combes, The Metaphor of Slavery in the Writings of the Early Church. From the New Testament to the Beginning of the Fifth Century, [Journal for the Study of the New Testament. Supplement Series, t. 156], Sheffield 1998, s. 52: ,... the rapid upward mobility of freedmen is a characteristic feature of the later Roman empire".

${ }^{14}$ Por. Pałucki, Dobre bogactwo, s. 5.

${ }^{15}$ Klemens mówi o nocnikach wykonanych ze srebra, kryształu, a nawet złota: „Kpiną i śmiechem jest to, że mężczyźni wożą ze sobą nocniki ze srebra i kryształu [...] i że głupie kobiety każą wykonywać sobie złote pojemniki na wypróżnianie się" (Clemens Alexandrinus, Paedagogus II 39, 2, GCS 12, s. 180-181, przekład polski M. Szarmach w: Klemens Aleksandryjski, Wychowawca, Toruń 2012, s. 107). Aleksandryjczyk mówi też o „pucharach ze srebra i złota, a także wysadzanych drogimi kamieniami” (Paedagogus II 35, 1, GCS 12, s. 177, Wychowawca, s. 104); wymienia „srebrne łoża, misy, naczyńka do octu, sosjerki, srebrne i złote wazy [...] artystycznie wykonane trójnogi z łatwego w obróbce i pachnącego cedru, hebanu i kości słoniowej, łoża na srebrnych nogach, tace z kości słoniowej aplikowane złotem, kolorowe skrzydła drzwi inkrustowane szylkretem, łoża wyściełane purpurą i innymi, trudnymi do zdobycia barwnymi tkaninami” (Paedagogus II 35, 3-4, Wychowawca, s. 104); wspomina też o klejnotach i kosztownej biżuterii (por. Paedagogus II 118-125, GCS 12, s. 227-232).

${ }^{16}$ Termin: „bogaty” był i jest pojęciem względnym. W starożytności ludzie bogaci „byli warstwą żyjącą, względnie mogącą żyć, bez osobistej zarobkowej pracy" (A. Rodziński, Sprawiedliwość chrześcijańska wobec problemu nierówności majątkowych w II i III wieku, Lublin 1960, s. 33).

${ }^{17}$ Naumowicz, Wstęp, s. 6. Sam Klemens charakteryzuje swych mistrzów w następujący sposób: „Z tych jeden przebywał w Helladzie, drugi był Jończykiem, inni zamieszkiwali w Wielkiej Grecji (z tych znowu jeden pochodził z Celesyrii, drugi z Egiptu). Inni przebywali na Wschodzie: 
lat osiadł w Aleksandrii - wielkim mieście hellenistycznym, gdzie spotkał nauczyciela - Pantena (Pantajnosa) ${ }^{18}$, z którym związał się na stałe. Pisma Klemensa wskazują, że był on doskonale wykształcony w wielu dziedzinach, zwłaszcza w filozofii. Interesował się zarówno literaturą grecką, jak i żydowską oraz chrześcijańską ${ }^{19}$. Z jego wykwintnego stylu i zawartości rozpraw również jasno wynika, że zarówno on sam, jak i jego czytelnicy musieli być członkami doskonale wykształconej elity ${ }^{20}$.

Obok wielu obszernych dzieł, Klemens jest również autorem niewielkiej pra-

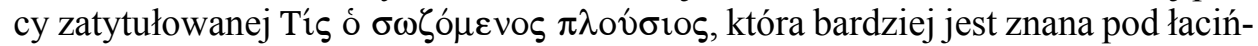
skim tytułem Quis dives salvetur? ${ }^{21}$ Pismo to ma kluczowe znaczenie dla podjętej $\mathrm{w}$ artykule problematyki ${ }^{22}$. Ogólnie przyjmuje się, że jest to homilia ${ }^{23}$ (lub kilka homilii połączonych $\mathrm{w}$ jedną całość $)^{24}$ na temat perykopy o bogatym młodzieńcu zawartej w Ewangelii według św. Marka (10, 17-31; por. Mt 19, 16-22; Łk 18, 18 23). Homilia ta powstała w Aleksandrii około roku $200^{25}$. Jest to także pierwszy znany komentarz do tego fragmentu Nowego Testamentu. Aleksandryjski Scholarcha dokonuje w nim analizy wskazania: „Idź, sprzedaj wszystko, co masz, i rozdaj ubogim" (Mk 10, 21). Uzasadniając zajęcie się tym fragmentem Pisma Świętego, Klemens czyni aluzję do pewnych problemów, które dotyczyły bogatszych członków aleksandryjskiej wspólnoty chrześcijańskiej. Należy zauważyć, że w czasie działalności Aleksandryjczyka do grona chrześcijan dołączało coraz więcej ludzi

jeden pochodził z Asyrii, drugi był Hebrajczykiem ze starego rodu w Palestynie. Gdym spotkał jednego z nich, jako ostatniego, a co do wpływu na mnie - pierwszego [tj. prawdopodobnie Pantena], zaprzestałem dalszych poszukiwań, wytropiwszy go w Egipcie, gdzie się ukrył" (Clemens Alexandrinus, Stromata, I 11, 2, GCS 52, s. 8, przekład polski J. Niemirska-Pliszczyńska, w: Klemens Aleksandryjski, Kobierce zapisków filozoficznych dotyczących prawdziwej wiedzy, t. 1, Warszawa 1994, s. 8.

${ }_{18}$ Por. Eusebius Caesariensis, Historia ecclesiastica, V 11, 2, SCh 41, s. 40. Szerzej zob. S. Lilla, Clement of Alexandria, Oxford 1971, s. 233-234; tenże, Panteno, w: NDPAC III, kol. 3818-3820 .

${ }^{19}$ Por. Naumowicz, Wstę, s. 9-10.

${ }^{20}$ Por. W. V. Harris, Ancient Literacy, Cambridge 1989; B. Pouderon, Réflexions sur la formation d'une élite intellectuelle chrétienne au II' siècle: les «écoles» d'Athènes, de Rome et d'Alexandrie, w: Les Apologistes chrétiens et la culture grecque, red. B. Pouderon, J. Doré, Paris 1998, s. 237-269.

${ }^{21} \mathrm{~W}$ literaturze polskiej dzieło to występuje pod tytułem Który człowiek bogaty może być zba-

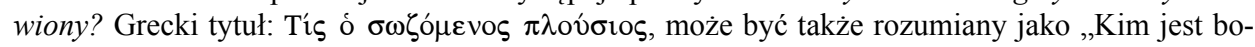
gaty człowiek, który jest zbawiony?” Wszystkie polskie teksty tego pisma pochodzą z przekładu autorstwa J. Czuja opublikowanego w: Klemens Aleksandryjski, Który człowiek bogaty może być zbawiony?, Pseudo-Klemens, Zachęta do wytrwałości, [MBOK 2], Kraków-Ząbki 1995, s. 41-119.

${ }^{22}$ Por. Pałucki, Dobre bogactwo, s. 10. Również w Stromatach - występując przeciw karpokracjanom głoszącym wspólnotę dóbr materialnych oraz gnostykom pogardzającym wszystkim, co jest materialne - Aleksandryjczyk prezentuje swe stanowisko wobec dóbr materialnych. Por. Naumowicz, Wstep, s. 12-13.

${ }^{23}$ J. Pałucki (Dobre bogactwo, s. 10) twierdzi, że dziełko Quis dives salvetur? nie jest „homilią wygłoszoną w czasie jakiejś funkcji liturgicznej”.

${ }^{24}$ Por. Naumowicz, Wstepp, s. 16.

${ }^{25}$ Por. Naumowicz, Wstęp, s. 5. 
bogatych ${ }^{26}$. Owi zamożni chrześcijanie źle rozumiejąc wskazanie Chrystusa (Mk 10, 25; Mt 19, 24; Łk 18, 25) tracili nadzieję osiągnięcia zbawienia lub nie podejmowali dostatecznych wysiłków, aby je zdobyć. Aleksandryjczyk pisze:

\begin{abstract}
Może różne przyczyny, a nie tylko jedna, sprawiają, że zbawienie ludzi zamożnych wydaje się nam trudniejsze niż zbawienie ubogich. Są bowiem tacy, którzy usłyszawszy przypadkiem i przelotnie słowa Zbawiciela: «Łatwiej wielbłądowi przejść przez ucho igielne, niż bogatemu wejść do królestwa niebieskiego» (Mk 10, 25; por. Mt 19, 24; Łk 18, 25), tracą wszelką nadzieję dostąpienia życia, a oddają się całkowicie światu i przywiązują do życia doczesnego, ponieważ sądzą, że ono tylko im pozostało. $\mathrm{W}$ ten sposób zbaczają z drogi zbawienia, bo nie zastanawiają się poważnie nad tym, kogo nasz Pan i Nauczyciel nazywa bogatym, ani nad tym, w jaki sposób możliwe staje się u Boga to, co jest niemożliwe u ludzi. Inni zaś zrozumieli to wprawdzie dobrze i właściwie, ale zaniedbawszy środki wiodące do zbawienia nie uczynili należytego przygotowania, aby dostąpić spełnienia swej nadziei ${ }^{27}$.
\end{abstract}

Klemens jasno daje do zrozumienia, że jego słowa nie są skierowane do wszystkich bogatych mieszkańców Aleksandrii. Podkreśla, że odnoszą się one jedynie do ludzi „wtajemniczonych” - do chrześcijan: „A jedno i drugie mówię o zamożnych, którym znana jest i moc Zbawiciela, i objawienie zbawienia. Niewiele obchodzą mnie ci, którzy nie są wtajemniczeni w prawdę"28. Uwaga ta wyraźnie wskazuje na fakt, że aleksandryjscy chrześcijanie, żyjący w czasach Klemensa, zastanawiali się nad problemem, czy przynależność do gminy chrześcijańskiej można pogodzić z posiadaniem dóbr materialnych?

Klemens zauważa także, że we wspólnocie aleksandryjskiej bogaci chrześcijanie posiadali drugorzędny status i dlatego upomina wszystkich wierzących, aby zachowywali się w sposób właściwy w stosunku do swoich współbraci ${ }^{29}$. Uwagi te ujawniają istnienie społecznych uprzedzeń wobec zamożnych chrześcijan. Z tego względu Klemens wyjaśnia:

Trzeba zatem, by ci, którzy kochają prawdę i braci swoich, a także nie potępiają bezwzględnie chrześcijan (por. 1 Kor 1, 24) zamożnych, ale i nie pochlebiają im dla własnej korzyści, przede wszystkim przez pouczenie ludzi bogatych uwalniali ich od niesłusznej rozpaczy i wykazywali przez właściwe wyjaśnianie słów Pańskich, że człowiek, który nie jest ubogi, może również stać się dziedzicem królestwa niebieskiego, jeśli będzie posłuszny przykazaniom ${ }^{30}$.

${ }^{26}$ Por. Rodziński, Sprawiedliwość chrześcijańska, s. 31.

${ }^{27}$ Clemens Alexandrinus, Quis dives salvetur? 2, GCS 172, s. 160-161, MBOK 2, s. 43-44.

${ }^{28}$ Clemens Alexandrinus, Quis dives salvetur? 2, GCS $17^{2}$, s. 161, MBOK 2, s. 44.

${ }^{29}$ Status ten wynikał prawdopodobnie z faktu, iż ludzie zamożni, choć stanowili znaczne grono, byli zdecydowaną mniejszością w gronie chrześcijan. Por. Rodziński, Sprawiedliwość chrześcijańska, s. 29. Pogański filozof Celsus (II w.) twierdził, że chrześcijanie zjednują sobie „wyłącznie głupców, prostaków, szaleńców, niewolników, proste kobiety i małe dzieci" (Origenes, Contra Celsum III 44, ed. M. Borret: Origène, Contre Celse, SCh 136, Paris 1968, s. 104, przekład polski S. Kalinkowski, w: Orygenes, Przeciw Celsusowi, [Pisma Starochrześcijańskich Pisarzy, t. 17/1], Warszawa 1977, s. 246).

${ }^{30}$ Clemens Alexandrinus, Quis dives salvetur? 3, GCS $17^{2}$, s. 161, MBOK 2, s. 44-45. 
Wydaje się, że przytoczone powyżej wypowiedzi Klemensa nie brzmią jak toposy literackie. Mogą więc odzwierciedlać rzeczywiste stosunki panujące między aleksandryjskimi chrześcijanami, lub przynajmniej tak oceniane przez naszego autora. Można zatem postawić tezę, że w aleksandryjskiej gminie chrześcijańskiej rzeczywiście istniały problemy i konflikty dotyczące nie tylko interpretacji, lecz także wdrażania w życie wspomnianego wskazania ewangelicznego ${ }^{31}$.

Klemens cytuje całą perykopę opowiadającą o spotkaniu bogatego młodzieńca z Chrystusem (Mk 10, 17-31) ${ }^{32}$ i twierdzi, że ten fragment Ewangelii św. Marka jest zbieżny $z$ innymi ewangeliami uznawanymi za autentyczne ${ }^{33}$. W opinii Aleksandryjczyka wszystkie mają tę samą wymowę, chociaż istnieją między nimi pewne drobne różnice w doborze słów. Aleksandryjski Scholarcha nie chciał najwyraźniej obciążać słuchaczy zbyt wieloma szczegółami z zakresu wiedzy o Nowym Testamencie. Mniej istotne były dla niego różnice tekstowe pomiędzy ewangeliami Marka, Mateusza i Łukasza, niż ogólna wymowa perykop. Twierdzi, że słów Ewangelii nie powinno się przyjmować dosłownie, ale - zgodnie z zasadami egzegezy aleksandryjskiej - należy szukać ich ukrytego znaczenia ${ }^{34}$ :

Otóż słowa te o bogatych, że trudno im wejść do królestwa, należy pojmować w sposób bardziej dociekliwy, a nie nierozumnie, po prostacku i zbyt dosłownie. Intencją ich bowiem jest wyrażenie głębszej myśli. I zbawienie nie polega na rzeczach zewnętrznych [...] ale na cnocie duszy: na wierze, nadziei, miłości (por. 1 Kor 13, 13), życzliwości braterskiej, wiedzy, łagodności, skromności i prawdzie, bo za nie właśnie nagrodą jest zbawienie. [...] Tak też można znaleźć nędzarza cierpiącego wielki niedostatek, któremu przytomność odbierają pożądliwości; a spotkasz także człowieka zamożnego, który jest jednak trzeźwy, ubogi w przyjemności tego świata, gorliwy, roztropny, czysty, opanowany ${ }^{35}$.

Wychodząc z tego założenia hermeneutycznego, Klemens od samego początku daje słuchaczom do zrozumienia, czego mogą się spodziewać. Nasz autor w pełni wykorzystuje tekst biblijny i analizuje go werset po wersecie, ale zastosowana przez niego metoda hermeneutyczna, w której naczelną rolę odgrywa poszukiwanie alegorycznego lub duchowego, ukrytego znaczenia słów biblijnych, służy podkreśleniu pierwotnego założenia. Przykładowo, dla zilustrowania swoich refleksji na temat poznania Boga, odwołuje się do Ewangelii św. Marka $(10,18)$ : „Czemu nazywasz Mnie dobrym? Nikt nie jest dobry, tylko sam Bóg”. Werset

${ }^{31}$ Por. Pałucki, Dobre bogactwo, s. 10.

${ }^{32}$ Jest to najdłuższy cytat biblijny ( 15 wersetów) obecny we wszystkich pismach Aleksandryjczyka. Por. M. Mees, Die Zitate aus dem Neuen Testament bei Klemens von Alexandrien, Bari 1970, s. $59-62$.

${ }^{33}$ Por. Clemens Alexandrinus, Quis divies salvetur? 5, GCS 17², s. 163, MBOK 2, s. 51-52: „To jest napisane w Ewangelii św. Marka; także i w innych jest podobnie, z małymi może w słowach zmianami, ale wszędzie znajdujemy tę samą zgodność myśli. A skoro wiemy dobrze, że Zbawiciel nie poucza nigdy swoich słuchaczy na sposób ludzki, ale wszystko im ukazuje w świetle Bożej, mistycznej mądrości, my także nie powinniśmy według ciała słuchać słów Jego".

${ }^{34} \mathrm{Na}$ temat Klemensowej egzegezy perykopy o bogatym młodzieńcu zob. A. Brontesi, La soteria in Clemente Alessandrino, Roma 1972, s. 73.

${ }^{35}$ Clemens Alexandrinus, Quis dives salvetur? 18, GCS 172, s. 171, MBOK 2, s. 70-71. 
ten skłania go do szczegółowych rozważań na temat wagi poznania Boga i tego, w jaki sposób można je osiągnąć:

Tak więc od samego początku należy wszczepiać w duszę największą i najgłówniejszą z nauk wiodących nas do życia; trzeba poznać Boga wiecznego i uznać Go dawcą wieczności - pierwszym, najwyższym, jedynym i dobrym Bogiem. A posiąść Go można przez wiedzę i zrozumienie ${ }^{36}$.

Kolejnym założeniem Klemensa jest konieczność ujarzmienia i w konsekwencji wyeliminowania irracjonalnych emocji i namiętności $\left(\pi \alpha \dot{\alpha} \theta \eta^{37}\right)$. Ostatnim zaś potrzeba szukania i dążenia do doskonałości. W pismach Klemensa tematy te są wszechobecne. Autor zręcznie wkomponowuje je w komentarze dotyczące tekstu biblijnego. W Quis dives salvetur? Aleksandryjski Scholarcha wprowadza temat doskonałości poprzez kompilację cytatów ewangelicznych. Bierze kilka słów z paralelnej perykopy Ewangelii św. Mateusza i włącza je do fragmentu pochodzącego z tekstu Ewangelii św. Marka: „Jeśli chcesz być doskonałym” (Mt 19, 21), „idź, sprzedaj wszystko, co masz, i rozdaj ubogim” (Mk 10, 21) $)^{38}$. Ta interpolacja daje mu okazję do przeanalizowania znaczenia doskonałości i bycia doskonałym oraz wolności woli człowieka $\mathrm{i}$ - w konsekwencji - problemu wolności człowieka zamożnego w wyborze drogi życia. Wiele ze wspomnianych motywów poruszanych jest w innych dziełach Klemensa, jednak w Quis dives salvetur? pojawiają się ich nowe aspekty. Nowe jest zaprezentowanie rozbudowanego komentarza na temat bogactwa i ubóstwa ${ }^{39}$, natomiast poszukiwanie ukrytych znaczeń umożliwia mu wyjaśnienie ,groteskowego" obrazu wielbłąda i ucha igielnego ${ }^{40}$.

Nie ulega wątpliwości, że tekst biblijny stanowi dla Klemensa punkt wyjścia. Jednak dla naszych rozważań istotna pozostaje przede wszystkim kwestia, co mu ten tekst mówi na temat bogactwa i ubóstwa oraz jak interpretuje on ten fragment? Nietrudno zauważyć, że Klemens chętnie pomniejsza oczywiste, płynące z literalnego rozumienia tekstu, surowe wnioski, co do zbawienia bogatych ${ }^{41}$. Zagłębia się w wyszukaną racjonalizację, posługując się w znacznej mierze argumentami zdroworozsądkowymi, przez co przeciwstawia się tym, którzy utrzymują, że biblijne wskazanie powinno być przyjmowane i interpretowane dosłownie:

«Sprzedaj, co masz» (Mk 10, 21). Co to znaczy? Nie żąda tu Zbawiciel, jak niektórzy zbyt pochopnie sądzą, aby porzucić posiadane mienie i wyrzec się majętności, ale poleca wyrwać z duszy powszechnie przyjęty sąd o bogactwach, przywiązanie do

${ }^{36}$ Clemens Alexandrinus, Quis dives salvetur? 7, GCS 172, s. 164, MBOK 2, s. 54.

${ }^{37}$ Termin $\pi \alpha ́ \theta \eta$ przyjmuje następujące znaczenia: „1. doznanie, wrażenie; 2. cierpienie, nieszczęście; choroby" [Słownik grecko-polski, red. Z. Abramowiczówna, t. 3, Warszawa 1962, s. 360 (dalej: Abramowiczówna 1-4). Por. H. G. Liddell, R. Scott, Greek - English Lexicon, Oxford 1958, s. 1285 (dalej: Liddell-Scott).

${ }^{38}$ Por. Clemens Alexandrinus, Quis dives salvetur? 10, GCS 17², s. 165-166.

${ }^{39}$ Klemens jest pierwszym pisarzem chrześcijańskim, który to czyni.

${ }^{40}$ Por. Ewangelia wedtug św. Marka, Wstęp - przekład z oryginału, komentarz, opr. H. Langkammer, Poznań -Warszawa 1977, s. 248, gdzie o. Hugolin Langkammer nazywa obraz ,groteskowym”. Klemens porównuje obraz z ciasną i wąską drogą (np. Quis dives salvetur 26, GCS $17^{2}$, s. 177).

${ }^{41}$ Por. Pałucki, Dobre bogactwo, s. 10-11. 
nich, nadmierną chciwość, niepokój o nie i namiętność, troski - ciernie życia, które zagłuszają nasienie wieczności (por. Mk 4, 19) ${ }^{42}$.

Aleksandryjski scholarcha jednoznacznie stwierdza, że wskazanie Chrystusa odnosi się nie tyle do porzucenia bogactwa, co do uwolnienia się od pożądania bogactwa i wyzbycia się innych wad. Zatem Chrystusowi nie chodziło o konieczność faktycznego sprzedania posiadanego majątku, lecz o wyzbycie się przywiązania do niego ${ }^{43}$. Zatem - zdaniem Klemensa - samo posiadanie bogactwa nie wyklucza nikogo z królestwa Bożego. Trzeba tylko zachować wolność duszy od nieuporządkowanego przywiązania do dóbr materialnych. Dlatego nieco dalej Aleksandryjczyk mówi:

Słów tych nie zrozumiał jak należało ów człowiek wielce bogaty i żyjący według Prawa. Nie pojął, jak można być ubogim i bogatym zarazem, mieć majątek i nie mieć go, używać tego świata i nie używać, odszedł więc smutny i przygnębiony ${ }^{44}$.

Następnie Klemens stwierdza, że bycie ubogim nie jest powodem do chluby, ani nie jest stanem pożądanym przez wielu. Swe rozważania prowadzi w taki sposób, który sugeruje niemalże pogardę dla ludzi ubogich. Utrzymuje także, że wyrzeczenie się bogactwa nie jest ideą nową, oraz że nie wiąże się z nim automatycznie żaden pożytek. Przeciwstawia się też literalnej interpretacji analizowanego tekstu biblijnego i wykazuje, że jeśli zostanie on potraktowany dosłownie, to pojawią się w nim pewne sprzeczności:

Ubóstwo zresztą nie jest rzeczą wspaniałą ani godną zazdrości, chyba że ktoś znosi je
dobrowolnie dla życia wiecznego. W ten sposób bowiem ludzie nic w ogóle nie po-
siadający, opuszczeni, zdobywający żebractwem codzienne utrzymanie, tułający się
po drogach biedacy, którzy nie znają Boga, byliby najszczęśliwszymi i najmilszymi
Bogu, jedynymi dziedzicami życia tylko dlatego, że są w skrajnej nędzy, niedostatek
w życiu cierpią i nie mogą zaspokoić nawet najskromniejszych potrzeb. Wyrzeczenie
się majątku, aby rozdzielić go między ubogich albo oddać ojczyźnie, nie jest czymś
nowym, gdyż wielu ludzi przed przyjściem Zbawiciela tak czyniło - jedni, by móc
swój czas poświęcić martwej mądrości, inni dla marnego rozgłosu i próżnej żądzy
sławy, tacy np. jak Anaksagoras, Demokryt czy Krates ${ }^{45}$.

${ }^{42}$ Clemens Alexandrinus, Quis dives salvetur? 11, GCS 172, s. 166, MBOK 2, s. 59-60.

${ }^{43}$ We wskazaniu tym dostrzega się echo stoickiego ideału ỏ $\alpha \alpha \dot{\alpha} \theta \varepsilon ı \alpha$; por. Clemens Alexandrinus, Quis dives salvetur? 21, GCS 172, s. 173.

${ }^{44}$ Clemens Alexandrinus, Quis dives salvetur? 20, GCS $17^{2}$, s. 172, MBOK 2, s. 74.

${ }^{45}$ Clemens Alexandrinus, Quis dives salvetur? 11, GCS 172, s. 166-167, MBOK 2, s. 60. Klemens wymienia trzech filozofów greckich z V-III wieku przed Chrystusem, którzy zrezygnowali z posiadania dóbr materialnych ze względów osobistych lub dla osiągnięcia chwały: Anaksagoras oddał swój majątek krewnym, aby poświęcić się całkowicie filozofii (por. Diogenes Laertius, Vitae philosophorum, II 3, 6-7, ed. R. D. Hicks: Diogenes Laertius, Lives of eminent Philosophers, [The Loeb Classical Library, t. 184], t. 1, London-Cambridge Mass. 1959, s. 134. 136); Demokryt, aby osiągnąć spokój wewnętrzny (por. Diogenes Laertius, Vitae philosophorum, IX 7, 36. 39, Hicks, t. 2, s. 444. 446. 448); cynicki filozof Krates z Teb spieniężył cały majątek i rozdzielił pomiędzy rodaków, aby całkowicie poświęcić się filozofii i prowadzić życie pozbawione potrzeb (por. Diogenes Laertius, Vitae philosophorum, VI 5, 87, Hicks, t. 2, s. 90). 
Klemens interpretuje ten fragment Ewangelii według własnych zasad. Utrzymuje, że właściwym przesłaniem wskazania biblijnego nie jest zewnętrzny akt porzucenia własności i wyrzeczenia się posiadanych dóbr materialnych, lecz coś o wiele bardziej twórczego i wzniosłego, a mianowicie odarcie duszy z jej namiętności ${ }^{46}$. Następnie przechodzi do ukazania negatywnego potencjału kryjącego się w wyrzeczeniu się majątku w kategoriach czysto egzystencjalnych. Nawet, gdyby ludzie pozbyli się dóbr materialnych, to mogłoby to nie powstrzymywać ich przed pożądaniem ich posiadania. Tłumaczy to w sposób następujący:

\begin{abstract}
Trzeba także zaznaczyć, że człowiek, chociaż się pozbył ciężaru mienia, może mieć jednak wrośniętą w duszę żądzę i pragnienie bogactwa nie mniej żywe: wyrzekł się wprawdzie jego używania, jednakże żyjąc w niedostatku i tęskniąc za dobrem zmarnowanym boleje podwójnie, bo odczuwa brak potrzebnych posług, a zarazem żal mu ich utraty. Nie ulega bowiem najmniejszej wątpliwości, że człowiek, któremu brak rzeczy koniecznych do życia, musi załamać się na duchu i porzucić swoje szlachetne dążenia; będzie natomiast starał się zdobyć to, co jest mu nieodzownie potrzebne, nie bacząc w jaki sposób i od kogo ${ }^{47}$.
\end{abstract}

Z tego punktu widzenia, człowiek, który wyrzeka się posiadanych dóbr materialnych, nie tylko nic nie zyskuje, lecz także pogarsza swój stan, gdyż zamiast skupić się na poznaniu i umiłowaniu Boga, zaczyna nadmiernie koncentrować się na swej doczesnej egzystencji:
A o ileż jest pożyteczniej, kiedy dzieje się przeciwnie: gdy człowiekowi wystarcza do życia to, co posiada, wtedy nie trudzi się nadmiernie zdobywając utrzymanie i może przychodzić z pomocą potrzebującemu. Jakaż bowiem wspólnota pozostałaby lu- dziom, gdyby nikt nic nie miał? ${ }^{48}$

W bardziej filozoficzny sposób Klemens wykazuje, że bogactwo samo w sobie jest moralnie obojętne $\left(\dot{\alpha} \delta \text { tó } \varphi \rho_{0} \rho \varsigma^{49}\right)^{50}$, a zatem ani dobre, ani $z^{51}{ }^{51}$. Jest ono narzędziem, i dlatego jego wartość moralna w dużej mierze zależy od tego, czy zostanie użyte właściwie, czy też nie, a nie od samego faktu posiadania go $^{52}$. Kle-

${ }^{46}$ Por. Clemens Alexandrinus, Quis dives salvetur? 14, GCS 17², s. 168-169.

${ }^{47}$ Clemens Alexandrinus, Quis dives salvetur? 12, GCS $17^{2}$, s. 167, MBOK 2, s. 62.

${ }^{48}$ Clemens Alexandrinus, Quis dives salvetur? 13, GCS 172, s. 167, MBOK 2, s. 62-63.

${ }^{49}$ Przymiotnik ỏ $\delta$ ió $\varphi 0 \rho o \varsigma$ przyjmuje następujące znaczenia: „1. nie różniący się, nie dający

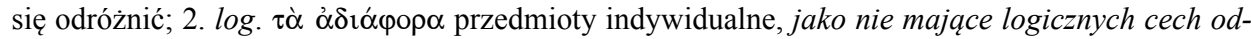

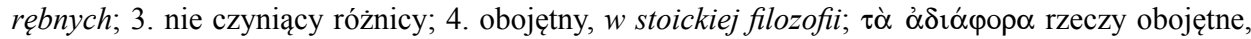
ani dobre, ani złe; 5. niezmienny, stały; 6. o osobach, nie robiący różnicy, traktujący jednakowo" (Abramowiczówna 1, s. 28). Por. Liddell-Scott, s. 22-23; G. W. H. Lampe, A Patristic Greek Lexicon, Oxford 1961, s. 35 (dalej: Lampe).

${ }^{50}$ Idea ta zaczerpnięto została od stoików, którzy uważali, że wszystkie rzeczy sytuujące się pomiędzy dobrem a złem moralnym są obojętne; por. G. Reale, Historia filozofii starożytnej, t. III: Systemy epoki hellenistycznej, przekład E. I. Zieliński, Lublin 1999, s. 400-406. Podobny motyw można znaleźć u Platona.

${ }^{51}$ Por. Clemens Alexandrinus, Quis dives salvetur? 14, GCS 1722, s. 168-169.

${ }^{52}$ Por. Clemens Alexandrinus, Quis dives salvetur? 15, GCS $17^{2}$, s. 169. Następnie w Quis dives salvetur? 31 (GCS $17^{2}$, s. 180), Klemens inaczej to formułuje, przyznając, że wszystkie posiadane dobra są z natury nieprawe, jeśli używane są dla osobistej korzyści. 
mens - czyniąc aluzję do ewangelicznej perykopy wspominającej o dobrym człowieku, który czyni dobry użytek ze swojego skarbu i o złym człowieku, z którego skarbu wynika zło (por. Mt 12, 35; Łk 6, 45) - przekonuje, że są dwa rodzaje bogactwa i ubóstwa, podobnie jak są dwa rodzaje skarbów ${ }^{53}$. Jeden rodzaj bogactwa jest godny pożądania i takie bogactwo warto mieć, drugi zaś jest niepożądany i bezwartościowy. To samo dotyczy ubóstwa. Odnosząc się do tej kwestii Klemens wyjaśnia:

W ten sam sposób błogosławione jest także ubóstwo, ale ubóstwo duchowe; dlatego dodał Mateusz: «Błogosławieni ubodzy» - jacy ubodzy? - «w duchu» (Mt 5, 3). A dalej: «Błogosławieni, którzy łakną i pragną sprawiedliwości Bożej» (Mt 5, 6). Nieszczęśni przeto owi inni ubodzy o przeciwnym nastawieniu wewnętrznym - pozbawieni Boga, wyzuci z tego wszystkiego, co ludzie zwykli posiadać, nieświadomi sprawiedliwości Bożej ${ }^{54}$.

Bogactwo można osiągnąć na wiele sposobów: albo poprzez uczciwą pracę, skromne życie i oszczędzanie pieniędzy, albo poprzez urodzenie się w zamożnej rodzinie:

Cóż bowiem złego czyni człowiek, który starając się i oszczędzając jeszcze przed swoim nawróceniem zebrał sobie majątek wystarczający do dostatniego życia? Albo - co jeszcze trudniej byłoby zganić - jeżeli sam Bóg, dawca losu, umieścił go od razu w domu takich ludzi, w rodzinie otoczonej dostatkami i możnej dzięki swemu bogactwu? Jeśli bowiem człowiek przez to, że niezależnie od swej woli urodził się w bogactwie, nie mógłby osiągnąć życia, to raczej Bóg-Stwórca byłby krzywdzicielem, skoro uznał go za godnego szczęścia doczesnego, ale życia wiecznego pozbawił. Na cóż w ogóle zdałoby się, by z ziemi wyrastało bogactwo, jeśli ono śmierć zbroi i żywi? Jeśli natomiast ktoś potrafi zrzec się władzy nad swoim mieniem, żyć skromnie i roztropnie, Boga jedynie szukać, Bogiem oddychać i z Bogiem obcować, ten oto jest ubogi według przykazań, wolny, niepokonany, zdrowy, a bogactwa zranić go nie mogą. Jeśli zaś postępuje inaczej, «łatwiej jest wielbłądowi przejść przez ucho igielne, niż takiemu człowiekowi wejść do królestwa Bożego» (Mk 10,25). Ów obraz wielbłąda, który ciasną i wąską drogą (por. Mk 10, 25; Mt 7, 14) przejdzie szybciej niż człowiek bogaty, musi zawierać w sobie jakiś sens głęboki, a ową tajemnicę Zbawiciela możemy poznać w wykładzie $O$ (pierwszych) zasadach $i$ teologii ${ }^{55}$.

Sytuację, gdy ludzie bogaci dzielą się swoim majątkiem z ubogimi i potrzebującymi wsparcia ${ }^{56}$, Klemens postrzega jako pewien rodzaj wymiany, która przyno-

${ }^{53}$ Por. Clemens Alexandrinus, Quis dives salvetur? 16, GCS $17^{2}$, s. 170.

${ }^{54}$ Clemens Alexandrinus, Quis dives salvetur? 17, GCS 172, s. 170-171, MBOK 2, s. 70.

${ }^{55}$ Clemens Alexandrinus, Quis dives salvetur? 26, GCS 172, s. 177, MBOK 2, s. 84-85. Klemens wymienia tu zaginione pismo, w którym omawiał zasady poznawcze i ontologiczne rzeczywistości oraz możliwość poznania Boga. Jest ono wspomniane też w Stromatach (III 13, 1, GCS 52, s. 201; 21, 2, GCS 52, s. 257). Por. P. Nautin, La fin des «Stromates» et les "Hypotyposes» de Clément d'Alexandrie, „Vigiliae Christianae” 30 (1976), s. 292-293.

${ }^{56}$ Klemens wyraża przekonanie, że człowiekiem prawdziwie bogatym nie jest ten, kto ma wielki majątek i stara się go jeszcze powiększyć, lecz ten, to posiadanymi dobrami chętnie dzieli się z ubogimi. Por. Clemens Alexandrinus, Paedagogus III 35, 4-5, GCS 12, s. 257, Wychowawca, s. 187: „Jeśli już trzeba rozróżniać, to bogatym nie jest ten, kto ma wiele i stale jeszcze napycha 
si zysk przede wszystkim tym, którzy hojnie udzielają jałmużny: „O, jakiż to zysk piękny! Jakaż boska zamiana! Za mienie swoje możesz nabyć nieśmiertelność, a oddając znikome dobra światowe otrzymać za nie w zamian wieczne mieszkanie w niebie" 57 .

Przytoczone wyżej wypowiedzi aleksandryjskiego scholarchy pozostawiają wrażenie, że zajmuje się on głównie problemami ludzi zamożnych. Pomimo, że stara się on równomiernie rozkładać swoją uwagę na ludzi bogatych i ubogich, widać, że nie jest w stanie uwolnić się od świadomości swego pochodzenia. Nawet, kiedy mówi o ludziach faktycznie biednych, czyni to z pozycji raczej uprzywilejowanej:

\begin{abstract}
Otwieraj serce swoje wszystkim, którzy są zapisani jako uczniowie Pańscy. Nie gardź dumnie nikim z powodu wyglądu zewnętrznego, nie lekceważ niebacznie młodości ani starości. A jeśli widzisz, że ktoś jest ubogi, źle ubrany, szpetny lub słaby, nie bądź $\mathrm{z}$ tego powodu dlań w duszy niechętny i nie odwracaj się od niego. Kształt to jedynie zewnętrzny, w który zostaliśmy przyobleczeni, kiedyśmy na świat przychodzili, bo do tej wspólnej wszystkim szkoły tylko tak odziani wejść możemy. Ale wewnątrz, w głębi duszy ukryty mieszka Ojciec i Jego Syn - Ten, który za nas umarł i z nami $\mathrm{z}$ martwych powsta ${ }^{58}$.
\end{abstract}

Już na pierwszy rzut oka wyraźnie widać, że w powyższej wypowiedzi nacisk położony jest nie na ludzi biednych, lecz na bogatych i ich społeczne obowiązki. Nieprzypadkowo Klemens często używa w tym kontekście słowa $\varphi \imath \lambda \alpha \nu \theta \rho \omega ́ \pi 0 \varsigma^{59}$, gdyż dzielenie się posiadanymi dobrami jest częścią systemu społecznego, w któ-

złotem swój brudny worek, przyzwoitym zaś jest człowiek sprawiedliwy, bo przyzwoitość to właściwe gospodarowanie i wypłacanie należności. «Acz są hojni, to stale bogaci, inni zaś, choć skąpi, zmierzają do nędzy» mówi o takich Pismo (Prz 11, 24), a gdzie indziej: «Rozdał i obdarzył ubogich, hojność jego będzie trwała zawsze» (Ps 111, 9). Tak więc bogatym nie jest ten, kto ma i swego strzeże, ale ten, kto daje. Zebrany majątek nie świadczy, że jest się szczęśliwym, ale zdolność dzielenia się nim".

${ }^{57}$ Clemens Alexandrinus, Quis dives salvetur? 32, GCS $17^{2}$, s. 181, MBOK 2, s. 97.

${ }^{58}$ Clemens Alexandrinus, Quis dives salvetur? 33, GCS $17^{2}$, s. 182, MBOK 2, s. 99-100. Perspektywa ta jest również wyrazista w innych pismach Klemensa - por. Paedagogus III 34, 1, GCS 12, s. 256, Wychowawca, s. 186: „Z bogactwa należy korzystać w sposób godny i dzielić się nim po ludzku, a nie prostacko i pyszałkowato”; II 120, 6, GCS 12, s. 229, Wychowawca, s. 157: „Nie przystoi, by jeden opływał w dostatki, podczas gdy większość cierpi biedę. Czyż nie przynosi większej chwały być dobroczyńcą dla wielu, niż mieszkać w luksusie? Czyż nie jest bardziej rozumne łożyć na ludzi niż na kamienie i złoto? Czyż nie przynosi większej korzyści zjednywanie sobie przyjaciół ozdobionych cnotami od nabywania bezdusznej biżuterii?"; III 35, 5, GCS 17², s. 257.

${ }^{59}$ Greckie słowo $\varphi \imath \lambda \alpha \nu \theta \rho \omega ́ \pi$ życzliwy, uprzejmy, grzeczny; o zwierzętach przywiąanych do człowieka, łagodny, oddany, wierny; $\mathrm{pl}$. uprzejmości, grzeczności; 2. o rzeczach, ludzki, łagodny, godny człowieka; miły człowiekowi, przyjemny; uprzejmy; o winie, szlachetny; zgodny z naturalnym uczuciem ludzkim; 3. o odżywianiu, obfity; o rozprawie lekarskiej, popularny, przystępny; 4. subst. przyjaźń, pakt przyjaźni; 5. adv. żyć w przyjaźni z kimś” (Abramowiczówna 4, s. 516); por. Lampe, s. 1476; Liddell-Scott, s. 1932. Por. Clemens Alexandrinus, Stromata II 82, 3, GCS 52, s. 156 [z odniesieniem do Filona Aleksandryjskiego (De virtutibus 28-31)]; II 86, 3, GCS 52, s. 158. 
rym uczestniczą zarówno biedni jak i bogaci ${ }^{60}$. Mają oni swoje własne, uzupełniające się role i potrzebują siebie nawzajem w systemie społecznego patronatu ${ }^{61}$. Staje się to wyraźniejsze we fragmencie, w którym Klemens mówi, że ludzie zamożni ze względu na swe sknerstwo, zachowują się jakby byli ludźmi ubogimi i w ten sposób stają się zhańbieni. Po zacytowaniu tekstu pochodzącego z Księgi Przysłów (10, 4; w wersji Septuaginty), w którym autor natchniony stwierdza, że „bieda hańbi człowieka”, Klemens interpretuje go w sposób następujący: „Pismo mówi: «Bieda hańbi człowieka». Chodzi tu o sknerstwo, z powodu którego bogaci nie dzielą się z drugimi, jakby niczego nie mieli’"62.

******

Przytoczone powyżej wypowiedzi Klemensa wyraźnie ukazują, że z jego punktu widzenia, ewangeliczną zachętę do wyrzeczenia się dóbr materialnych należy interpretować alegorycznie, gdyż odnosi się ona nie tyle do pieniędzy, czy innych wartości materialnych, co do ich pragnienia i niepohamowanego przywiązania do nich. To, co się dzieje wewnątrz ludzkiej duszy jest o wiele ważniejsze niż zewnętrzny stan bycia bogatym lub biednym. Gdy Klemens mówi o rzeczywistej zamożności materialnej, to broni jej jako instrumentu niezbędnego do czynienia dobra, zaś dzielenie się dobrami postrzega jako społeczny i religijny obowiązek ludzi bogatych. Utrzymuje, że zamożni chrześcijanie powinni odłożyć na bok egoizm i hojnie wydawać pieniądze na rzecz biedniejszych współwyznawców, którzy w zamian wstawialiby się do Boga za swoimi darczyńcami. Takie stanowisko wynikało z faktu, iż funkcjonujący wówczas na różnych poziomach system patronatu, przeważnie (choć nie zawsze) opierał się na zasadzie wzajemności: w zamian za względy i korzyści materialne beneficjanci świadczyli określone usługi oraz pomagali w umacnianiu statusu patrona. W kontekście pojawienia się chrześcijaństwa idea ta została nieco zmodyfikowana, jednak echo starych wzorców wciąż było zauważalne. Bogactwo powinno być używane mądrze, zgodnie z planem Boskim i w służbie innych chrześcijan, zaś beneficjenci, odwzajemnialiby się swoim darczyńcom przez wstawiennictwo i modlitwy do Boga. Łożenie na dzieła charytatywne Kościoła i wspieranie ludzi ubogich, podobnie jak filantropijna hojność w czasach przedchrześcijańskich, pozostawało w bezpośrednim związku z autorytetem i statusem osoby świadczącej je. Jest rzeczą oczywistą, że Klemensowi trudno było ukryć własne elitarne pochodzenie, a jego komentarze czynione były raczej z myślą o dawcach niż odbiorcach pomocy.

Klemensowa interpretacja ewangelicznej perykopy o bogatym młodzieńcu stanowi istotny punkt $\mathrm{w}$ procesie pogodzenia społecznej elity ekonomicznej zło-

\footnotetext{
${ }^{60}$ Idea przeznaczania własnego bogactwa dla wspólnego dobra społeczeństwa miała długą tradycję wśród elity cesarstwa rzymskiego, a zamożni członkowie warstw wyższych uważali za swój obywatelski obowiązek używanie prywatnych środków dla celów społecznych.

${ }^{61}$ Szerzej na ten temat zob. S. R. Holman, The Hungry Are Dying: Beggars and Bishops in Roman Cappadocia, Oxford 2001, s. 11.

${ }^{62}$ Clemens Alexandrinus, Paedagogus III 30, 4, GCS 12, s. 254, Wychowawca, s. 183.
} 
żonej z ludzi zamożnych ze wspólnotą chrześcijańską. Jest też próbą wskazania bogatym chrześcijanom ich miejsca i roli w Kościele lokalnym. Porzucenie dóbr materialnych nigdy nie stało się normą dla chrześcijan, ale dość często pojawiały się radykalne głosy wymagające takiej postawy ${ }^{63}$. Klemens - jak zauważa Elizabeth Clark - powiększa ewangeliczne ucho igielne (por. Mk 10, 25), aby w ten sposób zaprosić bogatych obywateli Aleksandrii, chętnie przeznaczających swe dobra materialne na cele społeczne, a zwłaszcza na pomoc dla ubogich, do wstąpienia w szeregi chrześcijan ${ }^{64}$.

${ }^{63}$ Do zrozumienia Quis dives salvetur? oraz jego społecznego i kulturowego tła wiele wniosło studium L. W. Countrymana (The Rich Christian in the Church of the Early Empire: Contradictions and Accommodations, New York 1980), w którym autor analizując miejsce bogatego chrześcijanina w Kościele pierwotnym, w centrum uwagi umieszcza dzieła Klemensa. Countryman analizuje wczesnochrześcijańskie podejście do zamożności, dawania jałmużny i religijnej wartości bogactwa, oraz niebezpieczeństw płynących z dóbr dla ich posiadaczy i dla Kościoła. Autor wykazuje, że pomimo, iż bogactwo budziło w Kościele pierwotnym mieszane uczucia, porzucenie własności nigdy nie stało się dla chrześcijan normą. Countryman sygnalizuje podstawowy problem polegający na tym, że Kościół przyznawał bogatym chrześcijanom centralną rolę we wspieraniu swoich instytucji i dostarczaniu środków finansowych, chociaż jednocześnie odmawiał im tradycyjnej nagrody w zamian za ich hojne dary. Innym studium zasługującym na uwagę jest praca doktorska obroniona w Oxfordzie, autorstwa Davida Paula O'Briena (Rich Clients and Poor Patrons: Functions of Friendship in Clement of Alexandria's Quis dives salvetur?, Oxford 2004). O'Brien proponuje wnikliwą analizę literacką i retoryczną Quis dives salvetur?, zaś do głównego zagadnienia podchodzi z punktu widzenia patronatu i przyjaźni. O’Brien podejmuje znaczny wysiłek, aby umiejscowić dyskurs Klemensa na tle innych grecko-rzymskich konwencji zarówno filozoficznych, jak i kulturowych. Szczególnie interesujący - w jego interpretacji wypowiedzi Klemensa - jest pomysł, że „biedni” mieli duchowo

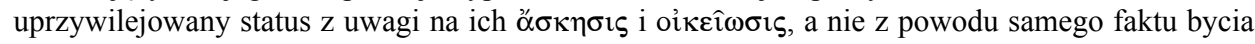
ubogimi $(\pi \varepsilon ́ v \eta \tau \varepsilon \varsigma)$. Teza, że podejście Klemensa może być postrzegane jako prekursorskie w stosunku do późniejszego obrazu „biednego” - męża świętego, który działa jako duchowy patron, jest ważna z punktu widzenia studium nad ascetyzmem i duchowością. Na gruncie polskim na uwagę zasługuje wspomniane już studium autorstwa J. Pałuckiego (Dobre bogactwo).

${ }^{64}$ Por. E. A. Clark, History, Theory Text: Historians and the Linguistic Turn, Cambridge (Massachusetts) 2004, s. 173: „Clement gladly widens the needle's eye to welcome the rich who generously give". 


\title{
CHRISTIANS AND RICHNESS IN THE TEACHING OF CLEMENT OF ALEXANDRIA
}

\begin{abstract}
Summary
In this article we present some statements of Clement of Alexandria (c. 150 - c. 212/215), in which he analyses a biblical pericope about the rich man from the Gospel according St. Mark (Mark 10,17-31; see also: Matthew 19,16-22, Luke 18,18-33). In a Clement's point of view, the evangelical advice to renounce material riches should be interpreted in an allegorical way, because that advice says rather about desire and unstopped attachment to material riches than about money or material worth itself. Everything what happens inside human soul is much more important than outer state of being rich or poor. Saying about real material richness Clement points that such richness is an indispensable tool of making good, while sharing with material goods is a social and religious duty of rich people. Wealthy people should wisely use their richness, according to God's plan and serving other Christians, while beneficiaries in return should intercede and pray for the givers to God. Clement's interpretation of evangelical pericope about the rich man is an important moment in a process of conciliating the economical elite of society with Christian community. It is also an effort to show the rich Christians their role and place in local Church.
\end{abstract}

